\title{
Sztuka mięs(n)a
}

Wglad jest jednorazowy. Jest momentem, ma jednak swoje istniejące $w$ czasie konsekwencje - nie można już wrócić do stanu poprzedniego. Nowa świadomość może być bolesna i straszna, może być doświadczeniem grozy, które daje się wyszeptać jedynie w poduszkę.

Olga Tokarczuk ${ }^{1}$

Najpierw należałoby doprecyzować, że chodzi tu o sztukę wizualną i sposoby pojawiania się mięsa w takim właśnie kontekście. Z jednej strony mięso może być wykorzystane jako materiał w taki sam sposób, jak drewno może być użyte do stworzenia rzeźby. $Z$ drugiej strony chciałabym zaprezentować prace, których tematem staje się mięso jako produkt spożywczy. Istotne będzie tu podejście poszczególnych twórców do wizualizacji odbiegającej od norm estetycznych przyjmowanych przez przemysł spożywczy, a dokładnie: przez producentów mięsa. Należałoby też zaznaczyć, że te normy estetyczne dotyczą określonych grup kulturowych, raczej przedstawicieli tych grup społecznych, które nie mają bezpośredniego kontaktu ze zwierzętami hodowlanymi. Jeśli ktoś spojrzałby na stragany, na których mięso sprzedawane jest na targowiskach w Polsce, lub wystawy małych sklepików we Włoszech czy też zajrzałby do meksykańskich sklepów w Kalifornii, to przyjęte tu założenie, a mianowicie, że mięso pozbawione jest swego naturalnego wyglądu zanim trafi na półki sklepowe, nie mogłoby być w pełni poparte przykładami.

Ta różnica pomiędzy sposobem pokazania mięsa w sztuce a wystawiania go na widok w centrach handlowych jest istotna, jeśli bierze się pod uwagę próby zacierania śladów wskazujących skąd mięso pochodzi. Powtórzę tu obserwację Hala Herzoga, który twierdzi, że większość Amerykanów tłumi poczucie winy, którego mogą doświadczyć, po prostu nie myśląc, skąd bierze się mięso na ich

1. Olga Tokarczuk, Moment niedźwiedzia, Wydawnictwo Krytyki Politycznej, Warszawa 2012, s. 43. 
obiad $^{2}$. Herzog przywołuje również badania przeprowadzone w Skandynawii, które pokazały, że przeciętni klienci odczuwają obrzydzenie, jeśli mięso wygląda bardziej realistycznie, to znaczy, im jest bardziej czerwone i „zwierzęce”, tym bardziej odpychające ${ }^{3}$. Badacze rynku zasugerowali więc przemysłowi mięsnemu, żeby ich produkty były mniej „cielesne”, żeby nie wyglądały jak rzeczywiste mięso. Małe kawałki gotowe do przygotowania, które pozbawione są koloru mięsa (czerwieni), budzą mniejszą odrazę. Mają przywoływać raczej wyobrażenie laboratoryjnej, bezbolesnej produkcji niż okrutnego uboju czy rzezi

Można w tym miejscu sięgnąć po pojęcie Realnego z psychoanalizy Lacanowskiej, aby odnieść się do artystycznego przedsięwzięcia podejmowanego przez niektórych twórców, kiedy to zmuszają odbiorców do zobaczenia czegoś, co tak skrzętnie przed ich wzrokiem ukrywają producenci mięsa. Obraz mięsa w sztuce stanowi przeciwieństwo takiej wizualizacji, jaka jest proponowana w supermarketach, sztuka mięsna to źródło bardziej ekstremalnego doświadczenia wizualnego.

Realne jest pojęciem, które pojawiło się w teorii Lacana w 1953 roku, równocześnie z pojęciami Symboliczne i Wyobrażeniowe. Tu pojawia się problem, jeśli chcielibyśmy podać zwięzłą definicję Realnego, ponieważ, podobnie jak inne pojęcia wprowadzane, zmieniane i porzucane przez Jacques'a Lacana, nie jest jednoznaczne. Nie jest też to pojęcie, które wszyscy zainteresowani teorią Lacana interpretują w taki sam sposób. Tutaj, odnosząc się do tego specyficznego „materiału” sztuki, przydatne będzie identyfikowanie Realnego z traumą oraz przyczyną strachu czy niepokoju.

Przyjmując ograniczenie, jakimi są ramy tego tekstu, spróbujmy chociaż częściowo przybliżyć pojęcie czy też kategorię Realnego i najprościej będzie to zrobić, sięgając po słownik, a mianowicie International Dictionary of Psychoanalysis. Martine Lerude pisze, że Lacan wprowadził pojęcie/kategorię Realnego w wykładzie Le symbolique, l'imaginaire et le réel (1953) i powiązał je, jak to już zostało wspomniane, z Wyobrażeniowym i Symbolicznym. Realne Lacanowskie nie powinno być kojarzone z Freudowską zasadą realności czy Wirklichkeit. U Lacana od razu pojawiła się kwestia Realnego w związku ze szkoleniem psychoanalitycznym, a istotnym był fakt, że Realne jest także definiowane przez szczególny sposób, w jaki podmiot jest w Realnym uwięziony. Lacan wykorzystywał też Objaśnienie marzeń sennych Freuda, aby wskazać, że Realne znajduje się u podstawy każdego snu oraz starał się objaśnić tę kategorię poprzez halucynację i psychozę. Rozwijając pojęcie prekluzji, czyli wykluczenia podmiotu, Lacan

2. Hal Herzog, Some We Love, Some We Hate, Some We Eat, Harper Perennial, New York 2011, s. 188.

3. Herzog, Some We Love..., s. 199.

4. Herzog, Some We Love..., s. 199. 
napisał w Écrits (1966), że to, co nie wychodzi na jaw w porządku symbolicznym, pojawia się w realnym. Natomiast w seminarium z 1978 roku, Cztery podstawowe pojęcia psychoanalizy, Realne jest wyjaśniane przez Lacana z wykorzystaniem pojęć przymusu i powtarzania. Powtarzanie, wywołane przez realne traumy, jest uwieczniane przez niepowodzenie symbolizacji. Teraz pojawia się nowy sposób definiowania Realnego przez Lacana, a mianowicie Realne staje się tym, co zawsze wraca do tego samego miejsca. Lacan skonceptualizował traumatyczne przeżycie jako Realne, które nie da się usymbolizować. W późniejszych seminariach, czyli w latach 1972-1978, Lacan twierdził, że te trzy kategorie: Realne, Symboliczne i Wyobrażeniowe są równoważne, a do wizualnej prezentacji tej równoważności wykorzystał trzy identyczne okręgi (węzeł boromejski). Od tej chwili, Realne w teorii Lacana nie było już czymś niejasnym i przerażającym, co nie daje się jednoznacznie określić, ale znalazło swoje miejsce obok Symbolicznego i zostało z nim związane za pośrednictwem Wyobrażeniowego ${ }^{5}$.

Slavoj Žižek w swoich tekstach sięga po pojęcie Realnego, ale jak można przeczytać w kolejnym słowniku (The Žižek Dictionary), bez wątpienia Realne jest jednym z najtrudniejszych do zdefiniowania pojęć zarówno u Lacana, jak i u Žižka. W tekście The Lacanian Real: Television Žižek pisze, że zazwyczaj Lacanowskie „Realne” jest przedstawiane jako twarde jądro opierające się symbolizacji, dialektyzacji, trzymające się swojego miejsca i zawsze do tego miejsca powracające. Jest to tylko jedna strona Realnego, która dominuje w tekstach z lat pięćdziesiątych, Realnego jako brutalnej przedsymbolicznej rzeczywistości, która zawsze wraca na swoje miejsce. Następnie, mówimy o porządku Symbolicznym, który nadaje strukturę naszemu postrzeganiu rzeczywistości, a w końcu o porządku Wyobrażeniowym, do którego zaliczane są byty iluzoryczne, których nie charakteryzuje realne istnienie, a są jedynie efektem strukturalnym.

W kolejnych latach nauczania, mówimy tu o latach sześćdziesiątych i siedemdziesiątych ubiegłego wieku, wraz z rozwojem Lacanowskiej teorii, to, co Lacan nazywa „Realnym”, coraz bardziej przypomina to, co w latach pięćdziesiątych nazywał Wyobrażeniowym. Paradoks Lacanowskiego Realnego polega więc na tym, że stanowi ono byt, który chociaż nie istnieje, jeśli rozumiemy to jako rzeczywiste istnienie, posiada kilka właściwości. Może sprawić, że jakieś efekty będą wywarte na symboliczną rzeczywistość podmiotów.

Žižek proponuje zdefiniowanie Realnego jako bytu paradoksalnego i chimerycznego, który stanowi jouissance par excellence w takim znaczeniu, że jouissance nie istnieje. Jouissance jest niemożliwe, ale powoduje mnóstwo traumatycznych skutków. Według niego, ta paradoksalna natura jouissance pozwala również wyja-

5. Martine Lerude, Real, The (Lacan), w: International Dictionary of Psychoanalysis, red. Alain de Mijolla, Thomas Gale, Detroit, New York 2005, s. 1453-1454. 
śnić fundamentalny paradoks, który nieustannie potwierdza obecność Realnego: fakt zakazania czegoś, co samo w sobie i tak jest niemożliwe ${ }^{6}$.

Kiedy Žižek zaczął się przyglądać węzłowi boromejskiemu, który Lacan zaproponował jako graficzne przedstawienie związku między porządkiem Realnym, Symbolicznym i Wyobrażeniowym, zwrócił uwagę na zależność tkwiącą jakby wewnątrz tych trzech porządków7. W przedmowie do For They Know Not What They Do pojawia się rozwinięcie pojęcia Realnego i Žižek proponuje, że istnieją trzy różne Realne. Jest więc „realne Realne”, czyli przerażająca Rzecz, pierwotny obiekt; „symboliczne Realne”, będące znaczącym zredukowanym do bezsensownego wzoru; „wyobrażeniowe Realne”, czyli niezgłębione „coś” ze względu na które w zwykłym przedmiocie można dostrzec coś wzniosłego ${ }^{8}$. To pierwsze Realne zaproponowane przez Žižka, a mianowicie Rzecz (das Ding) również stanowi przydatne pojęcie do opisu tej specyficznej relacji wobec mięsa, którą można zaobserwować u niektórych osób, które z jednej strony nie decydują się na rezygnację $\mathrm{z}$ jego spożywania, a $\mathrm{z}$ drugiej strony nie są $\mathrm{w}$ stanie zaakceptować tego „realnego" wyglądu mięsa. Duane Rousselle w słownikowym wyjaśnieniu pojęć wykorzystywanych przez Slavoja Žižka przypomina, że das Ding wykracza poza to, co jest elementem znaczonym, więc musi mieć swoje miejsce w Realnym, a jego najbardziej elementarną cechą jest wycofanie się z symbolizacji ${ }^{9}$.

W tym miejscu należy przypomnieć w jaki sposób pojęcie Rzeczy (das Ding) pojawiło się w psychoanalizie Lacana. Jacques Lacan ponownie odkrył dla nas pojęcie Rzeczy (das Ding), którym Zygmunt Freud posłużył się w Projekcie psychologii (Entwurfeiner Psychologie). Termin das Ding pojawia się w rozdziale Pamięć i osąd, gdzie Freud opisuje proces poznawania przez podmiot obrazów percepcyjnych, czy ujmując to bardziej ogólnie, rozważa pochodzenie naszej wiedzy. Zakłada on, że Nebenmensch, czyli bliźni, jest obiektem, który stanowi podstawę percepcji dziecka oraz że poprzez relację z bliźnim uczymy się poznawania ${ }^{10}$. Jednak pojawia się w tym miejscu specyficzne rozdwojenie, ponieważ, jak możemy przeczytać u Freuda, obiekt ten jednocześnie jest pierwszym obiektem satysfakcji podmiotu, ale

6. Slavoj Žižek, The Lacanian Real: Television, “The Symptom”, Fall 2008, 9, <http://www. lacan.com/symptom/the-lacanian.html> (5.07.2018).

7. Konfiguracje, które powstają można zapisać następująco: Realne-Realne, Realne-Symboliczne, Realne-Wyobrażeniowe, Symboliczne-Realne, Symboliczne-Symboliczne, Symboliczne-Wyobrażeniowe, Wyobrażeniowe-Realne, Wyobrażeniowe-Symboliczne oraz Wyobrażeniowe-Wyobrażeniowe. (Duan Rouselle, Real, Symbolic, Imaginary, w: The Žižek Dictionary, s. 215).

8. Slavoj Žižek, For They Know Not What They Do. Enjoyment as a Political Factor, Verso, London, New York 2002, s. xii.

9. Duane Rousselle, Real, Symbolic, Imaginary, w: The Žižek Dictionary, red. Rex Butler, Routledge, New York 2014, s. 216.

10. Sigmund Freud, Project for a Scientific Psychology, przel. James Strachey, w: The Standard Edition of the Complete Psychological Works, Vol. I, London 2001, s. 331. 
też obiektem, który budzi jej lub jego wrogie uczucia ${ }^{11}$. I tutaj właśnie napotykamy pojęcie rzeczy (das Ding), kiedy Freud pisze o rozdzieleniu bliźniego na dwie części, z których jedna jest czymś nowym i nieporównywalnym do niczego, co jest nam znane, a druga przypomina wspomnienia wizualnych doświadczeń podmiotu ${ }^{12}$.

Freud nazywa tę część percepcji, która nie może ulec asymilacji, „rzeczą” (das Ding), pisząc o tym, jak działa osąd, kiedy postrzegane jest coś, co może stanowić obiekt pragnienia ${ }^{13}$. Tego rodzaju postrzeżenia wzbudzają zainteresowanie i można w nich rozróżnić dwa komponenty, z których jeden, jako rzecz, nie da się zasymilować, a drugi, dzięki doświadczeniu, jest znany „ja”. Rzecz, czyli das Ding, jest czymś, co nie może być nazwane i z czym niemożliwa jest konfrontacja, ponieważ pozbawieni jesteśmy jakichkolwiek skojarzeń, które umożliwiłyby zrozumienie. Das Ding pozostaje poza podmiotem, a raczej należy do tego, co zewnętrzne, tego, co jako obce budzi trwogę. Freud twierdzi, że ,ja” podczas formowania osądu napotyka zarówno to, co jest znane, jak i to, co jest obce ${ }^{14}$.

Elvio Fachinelli zauważył, że to, co u Freuda było niewielkim punktem, u Lacana urasta do pustki czy też próżni mającej ogromne znaczenie i porównywalnej w swej sile kreowania nowego świata do Rzeczy, o której mówi Heidegger ${ }^{15}$. Lacan rozwija i opracowuje pojęcie das Ding w seminarium prowadzonym w latach 1959-1960, czyli w Etyce psychoanalizy. Rzecz dla Lacana jest fragmentem, który początkowo jest wyizolowany przez podmiot $\mathrm{w}$ doświadczaniu bliźniego (Nebenmensch), jako z natury obcy (Fremde), a osąd dzieli się na dwie częścici ${ }^{16}$. Tak więc Lacan powtarza to, co Freud pisał o naturze formowania osądu i odsyła nas do tekstu ojca psychoanalizy, aby odkryć, że rozwój podmiotu koncentruje się wokół das Ding jako czegoś obcego, a nawet wrogiego, ale zdecydowanie pierwotnie zewnętrznego ${ }^{17}$. Sugeruje on, że podmiot próbuje znaleźć punkty odniesienia w swojej relacji do świata pragnień, życzeń i oczekiwań, czy też czegokolwiek, co pozwoli na dosięgnięcie das Ding ${ }^{18}$. Jednakże, jak pisze Lacan, ten wyjątkowy obiekt, za którym tęskni podmiot, nie może być znaleziony, ponieważ w jego naturze leży bycie obiektem utraconym, który nigdy nie zostanie odzyskany ${ }^{19}$. W swoim seminarium Lacan odnosi się do das Ding jako obiektu utraconego, ale należy

11. Freud, Project for a Scientific Psychology, s. 331.

12. Freud, Project for a Scientific Psychology, s. 331.

13. Freud, Project for a Scientific Psychology, s. 366.

14. Freud, Project for a Scientific Psychology, s. 383.

15. Elvio Fachinelli, Lacan and the Thing, przeł. Gianmaria Senia, Claudia Vaughn, „JEP”, 1996/1997, nr. 3-4, <http://www.psychomedia.it/jep/number3-4/fachinelli.htm> (7.09.2007).

16. Jacques Lacan, The Ethics of Psychoanalysis, Seminar VII, przeł. Dennis Porter, London, New York 2008, s. 62.

17. Lacan, The Ethics of Psychoanalysis, s. 62.

18. Lacan, The Ethics of Psychoanalysis, s. 62-63.

19. Lacan, The Ethics of Psychoanalysis, s. 63. 
pamiętać, że objet a (obiekt małe a) pojawiający się, aby zasłonić niepowodzenie podmiotu w osiągnięciu tożsamości, także nazywany jest „utraconym obiektem”.

W swoim seminarium Etyka psychoanalizy Lacan dokonuje rozróżnienia między tym, co nazywa „rzeczą”, a tym, czym jest „przedmiot”20. Według niego przedmiot decyduje o kierunkach czy też biegunach przyciągania człowieka. Nie jest on Rzeczą, ponieważ przedmiot ma związek z ekonomią libidinalną ${ }^{21}$. Jednak status przedmiotu może ulec zmianie, ponieważ przedmiot jest wynoszony do godności Rzeczy (a mowa tu o Rzeczy z Freudowskiej topologii), o ile, jak pisze Lacan, nie jest on „wsunięty do, ale otoczony przez sieć Ziele”22. Ta zmiana ontologicznego statusu przedmiotu ma miejsce dzięki sublimacji i, jak czytamy w seminarium, można uważać, że sztuka funkcjonuje na poziomie sublimacji i wywołuje taką zmianę. Właśnie na tym poziomie, jak twierdzi Lacan, nie można oddzielić przedmiotu ani od wyobrażeniowego przedstawienia, ani od kulturowego przemyślenia i właśnie w tym miejscu pojawia się przestrzeń, w której zbiorowość „może się zwodzić w kwestii das Ding, może skolonizować obszar das Ding, używając wyobrażeniowych systemów"23. Lacanowska sublimacja pozbawia przedmiot jego celów, czyli Ziele, i zamiast tego lokuje go w miejscu zwanym Rzeczą, natomiast Freudowska sublimacja przekierowuje energię związaną z popędem z czynności seksualnej na nieseksualną.

Žižek, opierając się na książce Dariana Leadera Stealing the Mona Lisa, pisze, że „Sztuka i nauka uruchamiają proces sublimacji (tzn. tworzą dystans wobec naszego bezpośredniego doświadczania rzeczywistości), ale robią to na dwa różne sposoby"24. Jednak w przypadku niektórych prac artystycznych, o których będzie poniżej mowa, można by mówić o procesie wręcz odwrotnym, wydawać by się mogło, że to właśnie sztuka zapewnia bezpośrednie doświadczenie rzeczywistości (mięso nie poddane procesowi ukrywania jego naturalnego wyglądu). Oto przykłady sztuki mięs(n)ej, w której mięso jest używane w sposób, który może nawet wywołać traumatyczne przeżycia u widzów.

Jednym z takich przykładów, którego główną cechą był radykalizm w sposobie „uprawiania” sztuki, był projekt realizowany przez Akcjonistów Wiedeńskich. Grupa powstała na początku lat sześćdziesiątych w Austrii i zaliczali się do niej Otto Muehl, Günter Brus, Rudolf Schwarzkogler i Hermann Nitsch, który jako

20. Por. Martin Heidegger, Pytanie o rzecz, przeł. Janusz Mizera, Wydawnictwo KR, Warszawa 2001, oraz Rzecz, przeł. Janusz Mizera, w: Odczyty i rozprawy, Wydawnictwo Baran i Suszczyński, Kraków 2002, s. 145-164.

21. Lacan, The Ethics of Psychoanalysis, s. 137-138.

22. Lacan, The Ethics of Psychoanalysis, s. 138.

23. Lacan, The Ethics of Psychoanalysis, s. 122.

24. Žižek, Lacrimaererum. Kieślowski, Hitchcock, Tarkowski, Lynch, przeł. Kuba Mikruda, Paweł Mościcki, Korporacja ha!art, Kraków 2007, s. 139. 
jedyny z nich nadal jest aktywnym twórcą. Francuski historyk sztuki Jean Clair stwierdza, że tworzone przez nich Aktionen sprowadzały się do

działań publicznych, takich jak biczowanie i samobiczowanie, picie moczu i krwi, zjadanie ekskrementów, kopulacje ze zwierzętami czy odprawianie w religijnych szatach "czarnych" mszy ze składaniem ofiary ze zwierzą ${ }^{25}$.

Wnętrzności zwierząt, krew, ciała zwierząt rozciągnięte na krzyżu - to elementy nawiązujące do rytuałów ofiarnych, jakby chęć przywołania obrzędów, które już w starożytności potrzebowały zwierząt, a raczej ich śmierci, by symbolicznie reagować na rzeczywistość. Herman Nitsch, tworząc Teatr Orgii i Misteriów, przeniósł rytualne poświęcanie zwierząt do współczesności, a jednocześnie przeciwstawiał się burżuazyjnej estetyce preferowanej przez mieszkańców Wiednia. W katalogu z wystawy poświęconej Aktywizmowi Wiedeńskiemu możemy przeczytać, że

Sztuka według Nitscha zwraca uwagę na rzeczy wyparte ze świadomości i na fundamenty życia. Dzięki złamaniu tabu Nitsch konfrontuje widza, będącego równocześnie uczestnikiem spektaklu, z tematami egzystencjalnymi, a także społecznie częstokroć wypieranymi ze świadomości, jak na przykład seksualność, przemoc i śmierć26.

Chciałabym uniknąć tu artystycznej oceny jego dokonań, a jedynie zwrócić uwagę na fakt „urealnienia” mięsa, a także zastosowania go jako materiału twórczego. W Manifeście Teatru Orgii Misteriów Nitsch pisał:

[C]zwartego czerwca 1962 roku wypatroszę, rozedrę i rozszarpie na kawałki zdechłe jagnię. będzie to akt manifestacyjny („estetyczny” substytut aktu ofiarnego), który wraz z głębszym zbadaniem naukowych podstaw projektu teatru orgii misteriów okaże się zarówno sensowny, jak i konieczny. w swojej produkcji artystycznej (która jest forma kultu życia) mierzę się ze wszystkim, co wydaje się negatywne, niesmaczne, perwersyjne i obsceniczne, z pożądaniem i wywołaną przez nie histeria ofiarną, aby oszczędzić TOBIE wstydu i skalania się wynikających z popadnięcia w skrajność. jestem wyrazem wszelkiego stworzenia. połączyłem się z nim i utożsamiłem. Wszystkie cierpienia i pożądania, które połączą się w jeden stan dzikiego upojenia, ogarną mnie, a przez to i CIEBIE $^{27}$.

25. Jean Clair, De Immundo, przeł. Maryna Ochab, słowo/obraz terytoria, Gdańsk 2007, s. 50.

26. Mela Maresch, Andreas Hoffer, Günther Oberhollenzer, Akcjonizm Wiedeński, przeł. Sława Lisiecka, w: Akcjonizm wiedeński. Przeciwny biegun społeczeństwa, red. Stanisław Ruksza, Muzeum Sztuki Współczesnej w Krakowie, Kraków 2011, s. 17.

27. Herman Nitsch, Manifest Teatru Orgii Misteriów, przeł. Jan Burzyński (zachowana pisownia oryginału), w: Akcjonizm wiedeński. Przeciwny biegun społeczeństwa, red. Stanisław Ruksza, Muzeum Sztuki Współczesnej w Krakowie, Kraków 2011, s. 77. 
Nie była to jedyna jego deklaracja czy też opis planowanego performansu, w którym zwierzę stawało się mięsem - materiałem sztuki ${ }^{28}$.

W latach sześćdziesiątych powstał również performans Meat Joy, którego autorką była Carolee Schneemann. W 1964 roku performans wystawiono przed publicznością i sfilmowano. Na filmie możemy zobaczyć grupę kobiet i mężczyzn wijących się na podłodze wśród kawałków mięsa, gryzących surowe kawałki kurczaka lub ryby. Schneemann stwierdza, że Meat Joy przypomina erotyczny rytuał: nadmiernie ulegająca słabościom celebracja ciała jako materiału... miotającego się pomiędzy czułością, dzikością, precyzją, opuszczeniem: cechami, które mogą w każdej chwili stać się zmysłowymi, komicznymi, radosnymi, odpychającymi²9. Słowo „flesh” może oznaczać zarówno ciało, jak i mięso. Tutaj ludzkie ciała (flesh) wykorzystane są w podobny sposób jak mięso (flesh) - stają się materiałem sztuki. W performansie Schneemann nadmiar tej cielesności/,mięsności” zderza widzów z estetyką odległą od czegoś, co można określić jako „gust mieszczański”. Mięso pozbawione jest tutaj bezpośredniości, która będzie obecna w innych pracach, ale sposób, w jaki wyroby mięsne „obcują" z ciałami performerów może zbliżać patrzących do traumatycznego Realnego.

Innego rodzaju związek pomiędzy ciałem ludzkim a mięsem widzimy, kiedy artysta chińskiego pochodzenia, Zhang Huan, wykorzystuje mięso do performansu zaprezentowanego na ulicach Nowego Jorku. Surowe mięso posłużyło mu jako materiał do uszycia kostiumu wykorzystanego w My New York w 2002 roku. Huan ubrany w mięsny kombinezon przechadzał się ulicami miasta, a bodźcem do tego projektu była próba zrozumienia siebie w nowym kontekście, kontekście bycia imigrantem. Grube warstwy płatów mięsa skrywające jego sylwetkę tworzyły postać prawie komiksową, dodając mu niezwykłej muskulatury i masy. Ubrany w ten kostium, Huan uwalniał białe gołębice z klatki, który to gest stanowił część performansu, a może być interpretowany jako buddyjski gest współczucia. To, co zazwyczaj ukryte pod warstwą skóry (flesh), stało się widzialną warstwą. Odarte ze skóry zwierzęta nie są codziennym widokiem, odarci ze skóry ludzie nasuwają na myśl wymyślne tortury. Praca My New York czerpie swoją siłę z faktu, że współcześni mieszkańcy Nowego Jorku nie są przyzwyczajeni do widoku mięsa, które nie zostało poddane procesom pozbawiającym go swej bezpośredniości. Tutaj mięso nie jest produktem spożywczym, jest tworzywem, z którego powstała praca artystyczna.

28. Por. Akcjonizm Wiedeński. Przeciwny biegun społeczeństwa, red. Stanisław Ruksza, Muzeum Sztuki Współczesnej w Krakowie, Kraków 2011, s. 76-102.

29. " $[\mathrm{T}]$ he character of an erotic rite: excessively indulgent, a celebration of flesh as material... shifting and turning between tenderness, wilderness, precision, abandon; qualities which could at any moment be sensual, comic, joyous, repellent", Carolee Schneemann, Meat Joy, <http://www. caroleeschneemann.com/meatjoy.html> (2.04.2018). 
Nie była to pierwsza próba wykorzystania surowego mięsa w celu stworzenia ubrania. Jana Sterbak, kanadyjska artystka, jest najbardziej kojarzona z pracą Vanitas: Flesh Dress for an Albino Anorectic (1987), czyli sukienką uszytą ze steków. Praca ta wzbudziła wiele kontrowersji, kiedy została pokazana w Galerii Narodowej w Ottawie w 1991 roku. Sukienka zwisała z białego wieszaka, a obok na ścianie artystka umieściła fotografię ubranej w nią modelki. Modelka siedzi na podłodze, oparta na wyciągniętym ramieniu, a luźna suknia okrywa jej ciało. Tło, czyli jasna drewniana podłoga i biała ściana, stanowi wyraźny kontrast dla koloru sukni, jej wyrazistej czerwieni. Patricia Smart, pisząc o tej wystawie, wspomina czysto praktyczny aspekt związany z takim eksponatem, a mianowicie, w ciągu kilku tygodni mięso zaczęło się psuć i praca musiała być zastąpiona nową wersją ${ }^{30}$. Jednak nie dodatkowe koszty utrzymania wystawy były główną przyczyną protestów ze strony polityków, felietonistów i licznych autorów listów do redaktora, którzy określali pracę jako obrzydliwą, niewrażliwą, stratę pieniędzy podatników, a także symbol marnotrawstwa i braku wzajemnej troski między ludźmi. Protestujący skupili się jedynie na fakcie, że praca wykonana jest $\mathrm{z}$ tego konkretnego materiału i że jest to oczywiste marnowanie pożywienia w czasach, gdy bezdomni nie mają co jeśćc ${ }^{11}$. Smart zauważa, że aluzja do tematu vanitas popularnego $\mathrm{w}$ sztuce barokowej została zupełnie zignorowana $\mathrm{w}$ tych komentarzach, a także to, że praca może być interpretowana jako komentarz do kobiecego ciała czy mody ${ }^{32}$. Vanitas jako motyw sztuki wizualnej łączył idee piękna i przemijania. Wykorzystywane symbole miały na celu przypominać o przemijalności życia i dóbr materialnych, którymi ludzie się otaczają.

Kolejnym przykładem artysty, który umieścił surowe mięso wewnątrz galerii, jest Jannis Kounellis, artysta związany z włoskim Arte Povera, który kiedyś wykorzystał żywe konie jako materiał artystyczny, a w tej pracy rozwiesił wzdłuż ścian na hakach kawały wołowiny. Praca bez tytułu (Untitled) powstała w 1989 roku i została zaprezentowana w tym samym roku w galerii Espai Poblenou w Barcelonie. Można uznać takie działanie za przeniesienie do trójwymiarowej rzeczywistości obrazów, które wiele wieków wcześniej pojawiły się na płótnie. Zapewne tym najbardziej pamiętanym „kawałkiem wołowiny” jest obraz Rembrandta Rozpłatany wót. Ta późniejsza wersja z 1655 roku jest częściej używana jako ilustracja twórczości holenderskiego malarza ${ }^{33}$. Pewne podobieństwo

30. Patricia Smart, The Body Seen Through a Distorting Lens: Feminist Grotesque in the Art of Jana Sterbak and Louky Bersianik, w: Literature and the Body, red. Anthony Purdy, Rodopi, Amsterdam, Atlanta, GA 1992, s. 13.

31. Smart, The Body Seen Through a Distorting Lens..., s. 13.

32. Smart, The Body Seen Through a Distorting Lens..., s. 13.

33. W artykule ograniczam się do wykorzystywania mięsa jako materiału lub tematu w sztuce współczesnej, dlatego też liczne przykłady martwej natury, w której mięso lub martwe zwierzęta 
znajdziemy również w pracy Mony Hatoum - urodzonej w Bejrucie brytyjskiej artystki - Carcasses (Baalbeck) z 1998. roku. Wydruk chromogeniczny przedstawia zawieszone przed wejściem dwie tusze, prawdopodobnie wieprzowe, więc mamy kolejne medium (instalacja - Kounellis, obraz olejny - Rembrandt), które zostało użyte do przedstawienia podobnej kompozycji. Kolorystyka Carcasses (Baalbeck) koresponduje z obrazem Rozpłatany wół. Na obrazie jaśniejszy element to rozpłatane ciało wołu zwisające przed wejściem oraz niewyraźna postać kobiety w drzwiach i podobnie, w kompozycji Hatoum, ciała martwych zwierząt kontrastują z ciemnym tłem brązowego chodnika i prawie czarnym wnętrzem pomieszczenia. Carcasses (Baalbeck) zderzają patrzącą osobę z widokiem ciała zwierzęcia, które zostało zabite, aby stać się mięsem. Nie ma gdzie uciec wzrokiem, ponieważ ich centralne umieszczenie na pierwszym planie zdjęcia taką ucieczkę uniemożliwia. Mięso wykorzystane w pracy Hatoum niczego nie udaje.

Chociaż zapośredniczone przez fotografię, obrazy kawałów mięsa również mogą budzić równie silne emocje, jak surowe mięso, z którym odbiorcy mają bardziej bezpośredni kontakt. Helen Chadwick, brytyjska artystka urodzona w Londynie, stworzyła serię zdjęć polaroidowych zatytułowaną Meat Abstracts. Kompozycje wzorowane na obrazach przedstawiających martwą naturę - tutaj kawałki martwych zwierząt, jeśli dosłownie potraktujemy ten termin, są bardzo wyraziste. Ta wyrazistość została uzyskana przez dobór kolorystyki, oświetlenie i aranżację. Ann Jones pisze, że ważny jest również tutaj dobór sprzętu. Zdjęcia zostały wykonane aparatem wielkoformatowym firmy Polaroid (20" x 24") co umożliwiło wyraźne pokazanie szczegółu, co wraz ze specyfiką polaroidowego wydruku nadaje zdjęciom tak uwodzicielskiego charakteru ${ }^{34}$.

Patrzymy z zachwytem na zdjęcia, które mogłyby być uznane za piękne, do momentu, kiedy zdamy sobie sprawę, co tak pieczołowicie jest na kolorowych i błyszczących materiałach ułożone. To rozpoznanie przychodzi prawie natychmiast, ponieważ Chadwick nie próbuje nadać tym kawałkom surowego mięsa mniej realnego/naturalnego charakteru. Zamiast zachwytu odczuwać możemy odrazę, ponieważ realność mięsa, której staramy się unikać, przywodzi na myśl nasze wnętrzności, śmiertelność ciała, jest przedstawiona naszym oczom z (przesadną?) wyrazistością. Ann Jones zauważa, że taka smakowita aranżacja kawałków mięsa jest komiczna, a zarazem niepokojąca, ponieważ pochodzenie

stawały się elementami dominującymi w danej kompozycji malarskiej, nie są tu omawiane. Obraz Rembrandta został przywołany, ponieważ wyraźnie widać tu wizualne powiązanie pomiędzy tymi pracami. Rozpłatany wół pojawi się również na obrazie Francisa Bacona Figure with Meat, o którym będzie mowa w artykule.

34. Ann Jones, Meat Illuminated: Helen Chadwick's Meat Abstracts, <http://imageobjecttext. com/2014/01/03/meat-illuminated-helen-chadwicks-meat-abstracts/> (4.04.2018). 
mięsa na niektórych fotografiach nie jest takie oczywiste ${ }^{35}$. Nie możemy być w zupełności pewni, czy to aby nie ludzkie serce zostało sfotografowane na jednej z kompozycji. To, co możemy odczuwać, patrząc na te fotografie, może być również skomentowane przez następujący cytat:

[...] odraza wobec bezwładności życia. Nic nie oddaje lepiej podmiotowej postawy niż ta awersja, która świadczy o braku fantazmatycznej ramy, mogącej pośredniczyć między podmiotowością i nagą, realną substancją życia. Życie staje się odrażające, gdy rozpada się fantazja pośrednicząca w naszym dostępie do niego, tak że zostajemy bezpośrednio skonfrontowani z Realnym ${ }^{36}$.

Inny brytyjski artysta, Francis Bacon, uczynił mięso tematem niektórych swoich prac malarskich, czasem komponując je z sylwetkami ludzkimi, a francuski filozof Gilles Deleuze poświęcił jego twórczości książkę Francis Bacon: The Logic of Sensation (1981). Deleuze proponuje ideę ,uniwersalnego mięsa”, którą Bacon przywołuje, ponieważ, jak sugeruje Daniela Voss, nie oferuje on po prostu empirycznych obserwacji i przedstawienia wizualnego skręcania się i spazmatycznego bólu, którego doświadczają zarówno ludzie, jak i zwierzęta. Tworzy on wirtualną ideę uniwersalnego mięsa, ukazując afekty i percepty, które wywierają gwałtowny wpływ na naszą wysoko cenioną tożsamość i niszczą naszą potęgę mówienia ,ja”. Bacon ujawnia ukryte moce, które oddziaływają na mięso, a są nimi izolacja, deformacja i rozproszenie, rozciąganie i kurczenie się, łączenie się i rozdzielanie ${ }^{37}$. Deleuze w swej ocenie malarstwa Bacona podkreśla, że mięso jest jedynym obiektem współczucia Bacona, jego angielsko-irlandzkiego współczucia. To pozwala na porównanie go do Chaima Soutine’a i jego ogromnego współczucia dla Żyda ${ }^{38}$. Deleuze argumentuje, że mięso nie jest martwym ciałem, że zachowuje całe cierpienie i przybiera wszystkie kolory żywego ciała. $Z$ jednej strony manifestuje konwulsyjny ból i bezbronność, ale także kolory i ruch. Według Deleuze’a Bacon nie mówi „Współczujcie zwierzęciu”, ale raczej, że każdy człowiek, który cierpi, jest kawałkiem mięsa. Mięso stanowi wspólny obszar dla człowieka i zwierzęcia, ich obszar nierozróżnialności ${ }^{39}$. Deleuze pisze, że czasem Bacon zastępuje ludzką

35. Jones, Meat Illuminated...

36. Žižek, Lacrimaererum..., s. 108.

37. Daniela Voss, The Philosophical Concepts of Meat and Flesh:Deleuze and Marleau-Ponty, "Parrhesia", 2013, nr 18 <https://www.parrhesiajournal.org/parrhesia18/ parrhesia18_voss.pdf> (2.0.2018).

38. Chaim Soutine (1893-1943) był francuskim malarzem żydowskiego pochodzenia i jest zaliczany do ekspresjonistów. Wiele jego martwych natur przedstawia mięso w różnych „odsłonach”. Jest wśród nich również obraz nawiązujący do Rembrandta, a mianowicie Tusza wołowa (1925).

39. Gilles Deleuze, Francis Bacon: The Logic of Sensation, przeł. Daniel W. Smith, Continuum, London, New York 2003, s. 23. 
głowę głową zwierzęcia, ale nie należy odbierać tego jako formę zwierzęcą, a raczej jako cechę. Człowiek staje się zwierzęciem, ale zwierzę w tej samej chwili staje się duchem człowieka ${ }^{40}$.

W swoim ostatnim wywiadzie Francis Bacon powiedział „Flesh and meat are life!” (Ciało i mięso to życie!). Była to jego odpowiedź na pytanie zadane mu przez Francisa Giacobettiego „Co reprezentuje dla pana ciało?”. Bacon stwierdził, że maluje mięso tak samo, jak maluje ciała, ponieważ uważa, że są piękne. Szynka, świnie, języki, półtusze wołowe widziane w oknach wystawowych rzeźnika - całą tę śmierć Bacon uważa za piękną. A szczególnie surrealistycznym dla niego jest fakt, że to wszystko jest na sprzedaż ${ }^{41}$.

Obraz Figure with Meat powstał w 1954 roku i stanowi swoistą wersję portretu papieża Innocentego X, namalowanego przez Diego Velázqueza w roku 1650. W wersji stworzonej przez Bacona sylwetka papieża pokazana jest na tle wiszącego przepołowionego wołu. Wykorzystanie świeżego mięsa jako elementu kompozycji może ponownie przywoływać na myśl, jak to było w przypadku sukni stworzonej przez Janę Sterbak, malarstwo wykorzystujące symbole vanitas, których głównym przesłaniem były ostrzeżenia przed przyjemnościami zmysłowymi i nietrwałością życia. Już wcześniej wspomniany Rozpłatany wół Rembrandta stanowi element, do którego możemy się odwołać, patrząc na ten obraz. Mamy przed sobą kolaż stworzony z prac dwóch wielkich malarzy - Velázqueza i Rembrandta. Na ciemnym tle wiszący kawał mięsa jest jasną plamą wyraźnie odcinającą się od postaci papieża i przez to przykuwa wzrok.

Three Studies for a Crucifiction (1962) to tryptyk, forma, która tradycyjnie jest kojarzona $\mathrm{z}$ malarstwem o tematyce religijnej. Tutaj człowiek przechodzi transformację i staje się mięsem. Tutaj, w przeciwieństwie do poprzednio omawianego obrazu, tło to mieszczanina jasnych kolorów: żółci, pomarańczy, jasnej czerwieni. Na pierwszej części tryptyku, twarze dwóch mężczyzn przedstawionych na obrazie przeszły specyficzną przemianę - są zdeformowane i bardziej przypominają kawałki mięsa doczepione do korpusu na miejscu głowy niż ludzką twarz. W lewym dolnym rogu dwa elementy przypominające kawałki mięsa z kością są skierowane ku wnętrzu obrazu, wskazując na jednego z mężczyzn. Na drugim obrazie, w samym jego centrum, znajduje się kozetka, a leżąca na niej postać stanowi jakby formę przejściową między człowiekiem a kawałem mięsa. W leżącym kształcie możemy jeszcze odróżnić nogi i głowę, ale pozostałe części tego niby-ludzkiego ciała gdzieś się zatraciły i przywodzą na myśl raczej kawałki

40. Deleuze, Francis Bacon..., s. 21.

41. Francis Giacobetti, Francis Bacon, The Last Francis Bacon Interview, „The Art Newspaper”, June 2003, no. 137, s. 28-29 <https://www.americansuburbx.com/2015/02/francis-bacons-lastinterview-on-violence-meat-and-photography.html> (20.08.2018) 
mięsa, jakie można zobaczyć w rzeźni. Na białej poduszce, o którą opiera się postać, widać czerwone plamy. Na ostatniej części tryptyku nie ujrzymy już żadnej postaci ludzkiej. U dołu obrazu wyłania się głowa psa, który spogląda na kawał mięsa „zawieszony” w centrum obrazu. Kości i mięso zwierzęcia niewiadomego gatunku, a może to ostatnie stadium, w którym znalazła się postać z pierwszej części tryptyku. Tutaj to, co ludzkie (rozpoznawalny kształt sylwetki), uległo rozproszeniu w mięsie.

Chciałabym wykorzystać jeszcze jeden tryptyk Bacona, na którym ludzka twarz staje się mięsem: Three Studies for Portrait of Lucien Freud z 1965 roku. To portret(y) brytyjskiego malarza, wnuka Zygmunta Freuda, bliskiego przyjaciela Bacona przez 25 lat. Każdy z trzech obrazów namalowany jest w podobnej kolorystyce, tutaj wybrane kolory są zdecydowanie „mięsne”. Krwista czerwień, czerwień nieco wyblakła, czerwień przechodząca w róż, brązy sugerujące zakrzepłą krew. Nie takich kolorów zazwyczaj się spodziewamy na portretach. Na tych trzech obrazach Lucien Freud jest mięsem. Jego twarz wyraźnie zatraca ludzkie rysy. Jest jakiś zarys nosa, ust czy oczu, ale ulegają one deformacji, jakby zdjęto skórę, która nie pozwala, by ciało/mięso utraciły swój kształt. Łacińskie słowo protrahere znaczy wydobyć na światło dzienne, wyjawiać, pokazać, a więc moglibyśmy oczekiwać od portretu, że pokaże nam coś więcej niż tylko wygląd zewnętrzny portretowanej osoby, że ukaże nam jej psychikę. Francis Bacon pokazuje, że człowieka można zredukować do mięsa i w tym nie będzie różnić się od zwierząt, które właśnie do takiego stanu są bezrefleksyjnie redukowane. Możemy też zauważyć, że to twarz z koszmaru nocnego lub z horroru, spotkanie z taką twarzą to spotkanie z traumatycznym Realnym. Jeśli nawiążemy do proponowanej przez Freuda teorii percepcji drugiego człowieka przez dziecko, to twarz z Three Studies for Portrait of Lucien Freud staje się das Ding, tą rzeczą, którą nie da się porównać do niczego, co jest nam znane.

Mięso, które stawało się materiałem twórczym lub stanowiło tematykę prac tworzonych z wykorzystaniem różnych mediów w przedstawionych powyżej pracach, było łatwo rozpoznawalne i właśnie ta jego realność i namacalność była istotnym elementem doboru omawianych przykładów. Chociaż prace stworzone przez Heide Hatry odbiegają od tego schematu, stanowią ciekawy przykład wykorzystania mięsa jako materiału twórczego. Heide Hatry jest niemiecką artystką neokonceptualną, kuratorką i redaktorką pracującą w Berlinie i w Nowym Jorku. Jej prace - często związane z ciałem lub z wykorzystaniem zwierzęcego ciała i organów - wzbudzają kontrowersje i są uznawane przez niektórych krytyków za przerażające, odrażające lub sensacyjne, inni zaś nazywają ją „prowokatorką wyobraźni”. Jednym z projektów, w którym Hatry wykorzystała mięso, jest Heads and Tales z 2009 roku. Jak sama artystka wyjaśnia, portrety Heads and Tales to fotograficzne dokumentacje rzeźb poświęconych problematyce przemocy, 
śmierci i tożsamości płciowej. Chciała, aby były one jak najbardziej realistyczne, sugestywne, a czasami ustawione w pozycjach sugerujących ruch. Użyła nieprzetworzonej świńskiej skóry do pokrycia rzeźb, które wykonała z gliny, wykorzystała surowe mięso na usta i świeże oczy świni, aby portret wyglądał tak, jakby patrzył na widza z pełnym życia wyrazem twarzy, który fotograf właśnie uchwycił $w$ danym momencie ${ }^{42}$. Pisząc o tej pracy, Magdalena Jacyno zauważa, że

[n]aturalistycznie opracowane modele kobiecych głów (wpływa na to zarówno faktura, jak i kolor świńskiej skóry) są tak bardzo zmysłowe, że można je potraktować niczym metonimię ludzkiego ciała. W tej perspektywie „bycie człowiekiem” zatraca swój klarowny kontur na rzecz fluktuacyjnej fuzji z „pozaludzką zwierzęcością”. Przypomina to o czymś, o czym na co dzień nie chcemy pamiętać: że w rzeczywistości, pod względem biologicznym człowiek niewiele różni się od innych zwierzą ${ }^{43}$.

Do tych prac można również zastosować określenie, które zaproponował Deleuze, a mianowicie „uniwersalne mięso”. Tutaj ów uniwersalność polegałaby na łatwości, z jaką mięso ludzkie zastąpione zostaje nie-ludzkim i bez komentarza dodanego przez samą artystkę zapewne niełatwe byłoby skojarzenie tego szczególnego materiału, który wykorzystała $\mathrm{z}$ (nie)żywą materią pochodzenia zwierzęcego. Korzystając z refleksji innego francuskiego myśliciela, można również zauważyć, że tutaj skóra staje się fantazmatem zakrywającym Realne mięsa, ale można zasugerować, że w momencie poznania pochodzenia elementów, z których rzeźby powstały fantazmat ten ulegnie zniszczeniu.

Jacyno w swoim komentarzu do tej właśnie pracy przywołuje również termin, którego w stosunku do mięsa, jako materiału sztuki, jeszcze nie użyłam, a który również może stanowić jedno z narzędzi interpretacyjnych. W artykule Heide, ty świnio! możemy przeczytać, że

[u]czucie wstrętu, jakie zazwyczaj ogarnia nas w kontakcie z tego rodzaju abiektem (mięsem), dzięki estetycznemu potraktowaniu zostało przekroczone, przecząc czającym się okropnościom. Plugawe, śmiertelne komponenty, przybrawszy formę wnętrza i przykryte skórną warstwą, przestały zagrażać naszej własnej integralności ${ }^{44}$.

Nie jestem pewna, czy wszyscy traktują mięso jako abiekt i odczuwają wstręt, ale z pewnością pojęcie abiektu można zastosować, interpretując wszystkie te prace, w których mięso jest wizualnie dostępne w bardziej bezpośredni sposób. Julia

42. Heide Hatry, Statement <https://www.heidehatry.com/art_statementHT.html> (28.08.2018).

43. Magdalena Jacyno, Heide ty świnio!, w: „Magazyn Sztuki”, grudzień 2014, nr 5, s. 74.

44. Jacyno, Heide ty świnio!, s. 73. 
Kristeva, wprowadzając pojęcie abiektu, czyli czegoś, co nie jest ani podmiotem, ani przedmiotem, sugerowała:

Kiedy opanowuje mnie wstręt, ten splot afektów i myśli, który nazywam w ten sposób, właściwie nie ma on określonego przedmiotu. To, co wstrętne, wy-miot [abject], nie jest jakimś przed-miotem [unob-jet] naprzeciw mnie, któremu „ja” nadaję nazwę lub który sobie wyobrażam. Wy-miot nie jest też owym przedmiotem-gry [l’ob-jeu], małym „a”, nieskończenie się wymykającym w systematycznym poszukiwaniu przez pragnienie. [...] Każde „ja” ma swój przedmiot, każde „nad-ja” ma to, co wstrętne [wymiot] $]^{45}$.

Hal Foster zauważa, że abiekt „[j]est zarazem obcy podmiotowi i intymnie z nim związany; wręcz mocno związany, gdyż właśnie ta nadmierna bliskość wywołuje w podmiocie panikę" ${ }^{36}$. Pojęcie abiektu zostało też wykorzystane do opisu dzieł sztuki, które wykorzystują materiały zdegradowane. Termin abject art (sztuka wstrętu) jest używany do opisywania dzieł sztuki, które wykorzystują tematy przekraczające nasze poczucie czystości i przyzwoitości lub mu zagrażają, szczególnie są to normy odnoszące się do ciała i jego funkcji. Abject art ma silny kontekst feministyczny, ponieważ funkcje kobiecego organizmu są naznaczane jako abiekt przez patriarchalny porządek społeczny. W latach osiemdziesiątych i dziewięćdziesiątych XX wieku wielu artystów dostrzegło tę teorię i odzwierciedliło ją w swoich pracach. W 1993 roku w Whitney Museum w Nowym Jorku zorganizowano wystawę Abject Art: Repulsion and Desire in American Art, która przyniosła temu terminowi większą popularność użycia w sztuce ${ }^{47}$. Foster wywodzi natomiast sztukę abiektu z wcześniejszych działań artystycznych, a mianowicie od strategii stosowanej przez surrealistów:

Zasadniczo można jednak powiedzieć, że sztuka abiektalna zmierzała w dwóch kierunkach Jak już sugerowałem, pierwszy polegał na identyfikacji z abiektem, na próbie zbliżenia się do niego, aby zbadać ranę traumy, dotknąć obscenicznego przedmiotu-spojrzenia Realnego. W drugim chodziło o takie przedstawienie bycia abiektem, aby sprowokować jego odrzucenie - uchwycić na gorąco moment odrzucenia, poddać go refleksji, kiedy należną wartość zyska jego odpychający charakter ${ }^{48}$.

45. Julia Kristeva, Potęga obrzydzenia, przeł. Maciej Falski, Eidos Wydawnictwo Uniwersytetu Jagiellońskiego, Kraków 2007, s. 8.

46. Hal Foster, Powrót Realnego, przeł. Mateusz Borowski, Małgorzata Sugiera, Universitas, Kraków 2010, s. 183.

47. Abject art, <https://www.tate.org.uk/art/art-terms/a/abject-art $>(30.08 .2018)$.

48. Foster, Powrót Realnego, s. 186. 
Heidi Hatry była również kuratorką wystawy Meat After Meat Joy ${ }^{49}$, pokazanej w 2008 roku w Pierre Menard Gallery w Cambridge, Massachusetts, oraz w Daneyal Mahmood Gallery w Nowym Jorku. Z jednej strony było to nawiązaniem do performansu Carolee Schneemann, a z drugiej szansą prezentacji artystów, którzy wykorzystują mięso jako materiał w pracy twórczej. W wystawie wzięli udział następujący twórcy: Sheffy Bleier (Izrael), Lauren Bockow (USA), Adam Brandejs (Kanada), Tania Bruguera (Kuba), Nezaket Ekici (Niemcy/Turcja), Anthony Fischer (USA), Betty Hirst (USA), Zuang Huan (Chiny), Tamara Kostianovsky (Argentyna), Simone Racheli (Włochy), David Raymond (USA), Dieter Roth (Niemcy), Carolee Schneemann (USA), Stephen J. Shanabrook (USA), Jana Sterbak (Kanada), Jenny Walton (USA), and Pinar Yolacan (Turcja). W wywiadzie, którego Harty udzieliła jako komentarza do wystawy, przyznała ona, że pomysł wystawy wiązał się z jej własną twórczością. Od dawna pracowała ze skórą i mięsem oraz zebrała sporą dokumentację dotyczącą innych artystów pracujących $\mathrm{z}$ tymi samymi mediami. Kiedy dowiedziała się o kilku artystach z Bostonu, którzy tworzyli podobne prace, na przykład malarze Anthony Fisher i David Raymond, skorzystała ze swojej wiedzy, aby stworzyć wystawę grupową, która miałaby rozszerzyć tę koncepcję i przyciągnąć uwagę do możliwości jakie ona daje. Na pytanie Christiana Hollanda, czy chciałaby zmienić sposób postrzegania mięsa przez osoby odwiedzające wystawę, artystka odpowiedziała, że dla niej mięso jest pierwotnym faktem życia, nawet jeśli jest wysoce problematyczne. Myśli, że jej pociąg do mięsa jako materiału i tematu jest polisemiczny: ona nie jest szczególnie zainteresowana zmienianiem stosunku jednostki do mięsa, istotniejsze zaś dla niej jest nasilanie napięć w naszym ludzkim związku z mięsem ${ }^{50}$.

Do tej pory przedstawiałam prace, w których mięso było użyte jako materiał twórczy albo było pokazane w sposób nieukrywający jego realnego charakteru. Natomiast instalacja Banksy'ego, brytyjskiego artysty streetartu, stworzona w 2008 roku, ma zupełnie inny charakter. The Village Pet Store and Charcoal Grill konfrontuje odbiorców z tak skrzętnie skrywanym przez producentów mięsa faktem, skąd się biorą kawałki panierowanego kurczaka czy paluszki rybne. Instalacja została zaprezentowana w sklepie dla zwierząt w Greenwich Village, w Nowym Jorku. Szyld sklepu był zarazem tytułem instalacji. Wcho-

49. PETA (People for the Ethical Treatment of Animals) wydała komunikat prasowy, aby wezwać do zamknięcia wystawy. Tracy Reiman, Pierwsza Wiceprezes PETA, argumentowała, że jeśli ktoś nie jest Hannibalem Lecterem, mięso nie ma w sobie nic artystycznego lub radosnego. Stwierdziła, że jeśli niedopuszczalne jest zabijanie ludzi w celu stworzenia eksponatu sztuki, niedopuszczalne jest również zabijanie zwierząt. Zob. Sarah Sliwa, Meat After Meat Joy $<$ http://magazine.art21. org/2008/08/16/meat-after-meat-joy/\#.W4z0E7jzL18> (20.08.2018).

50. Holland Christian, Heide Hatry, Meat After Meat Joy <https://www.heidehatry.com/ meat_after_meat_joy.html> (4.08.2018). 
dząc do środka, można było zobaczyć pływające w akwariach paluszki rybne, panierowane kawałki kurczaka schylające "głowy” do pojemniczków z keczupem, czy hot dogi wijące się w terrarium. Cały sklep został wypełniony stworzeniami, które były pożywieniem wszechobecnym w amerykańskich domach. Giovanni Aloi skomentował tę pracę jako bardzo realistyczne użycie animatroniki w celu ponownego połączenia jedzenia ze zwierzętami, z których powstało ${ }^{51}$. To nie przypadek, że wszystkie użyte ,jedzeniowe” zwierzęta należą do kategorii żywności wysoko przetworzonej. To bardzo wyraźny komentarz Banksy’ego odnoszący się do codziennego dystansowania się od zwierząt, a zarazem przypomnienie, że jedzenie, które kupujemy, kiedyś było żywym zwierzęciem ${ }^{52}$. Aloi twierdzi, że dzięki tej instalacji niegdyś żywe zwierzęta do pewnego stopnia odzyskują swoją zwierzęcość poprzez symulowane ponowne nabycie cech zachowania ${ }^{53}$.

Na koniec posłużę się rysunkiem wykonanym przez Sue Coe, angielską artystkę i ilustratorkę wykorzystującą rysunek, grafikę oraz tworzącą ilustracje książkowe i komiksy. Jej twórczość opiera się na tradycji sztuki protestu społecznego. Prace Coe często zawierają komentarz dotyczący praw zwierząt. Wspomniany rysunek przedstawia duchy zwierząt, które zostały zabite, aby stać się pożywieniem, a teraz podążają za mężczyzną. Modern Man Followed by the Ghosts of His Meat pochodzi z 1990 roku. Praca jest czarno-biała, co według Aloi ma podkreślać upiorną atmosferę ${ }^{54}$, ale torebka $\mathrm{z}$ rozpoznawalnym logo McDonalda jest namalowana w kolorze, a więc przyciąga naszą uwagę. W tle widać witrynę sklepu rzeźnika $\mathrm{z}$ wiszącymi kawałkami mięsa i przetworami. Aloi sugeruje, że praca ta domaga się etycznej odpowiedzialności ${ }^{55}$. W przeprowadzonym przez Giovanni Aloi wywiadzie Coe powiedziała, że pomysł na ten rysunek wyniknął z zastanawiania się nad ukrytymi konsekwencjami naszego działania oraz jakby to było, gdyby stworzenia, które skrzywdziliśmy, zawsze podążały za nami. Jakby to było, gdyby one nigdy nie znikały z naszego pola widzenia ${ }^{56}$.

Sztuka mięs(n)a to sztuka konfrontacyjna. Niezależnie czy jest to sposób użycia surowego mięsa, czy prezentowania go za pomocą innych mediów, czy jest próbą skonfrontowania przeciętnych konsumentów $\mathrm{z}$ wypieranym przez nich faktem skąd się bierze mięso, które spożywają. To, co zostało przez nich wyparte w życiu codziennym, powraca w sztuce. To wyparcie ma długą historię. W XIX wieku Wielka Brytania i Francja wprowadziły prawne, geograficzne i architektoniczne

51. Giovanni Aloi, Art and Animals, I.B. Tauris, London, New York 2012, s. 49-50.

52. Aloi, Art and Animals, s. 50.

53. Aloi, Art and Animal, s. 51.

54. Aloi, Art and Animal, s. 136.

55. Aloi, Art and Animal, s. 136.

56. Giovanni Aloi, Sue Coe, In Conversation with Sue Coe, „Antennae. The Death of the Animal", Spring 2008, Issue 5, s. 59. 
ograniczenia w kwestii eksponowania zabijania zwierząt na widok publiczny. Antropolożka Noëlie Vialles w badanych przez siebie francuskich rzeźniach skupiła się na tym, jak zostały zaprojektowane. Okazało się, że projekt wnętrz zapewnia wzajemną niewidoczność zarówno dla pracowników rzeźni, jak i zwierząt, a także dla zwierząt umierających i tusz zwierzęcych ${ }^{57}$. Podobna „niewidzialność” jest zauważalna również na późniejszym etapie. Pedersen komentuje, że końcowy produkt tego procesu (kawał mięsa) jest pozbawiony uprzedniego znaczenia i wyzysku, który go wyprodukował, albo ma znaczenie, które zostało silnie okrojone, zmanipulowane, uszkodzone lub odcięte ${ }^{58}$. Truizmem będzie stwierdzenie, że wzrok jest dla większości z nas zmysłem, który wykorzystujemy jako narzędzie poznawcze. Okulocentryzm można uznać za cechę charakterystyczną dla kultury Zachodniej, dlatego to, co ukryte przed naszym wzrokiem przestaje budzić niepokój.

Claire Brunner, autorka artykułu The Flesh House oraz serii zdjęć, które wykonała w 2007 roku, przedstawiających miejsca przechowywania mięsa, starała się również spojrzeć na nasz stosunek do mięsa i ciała z historycznego punktu widzenia. Odkryła, że zmienił się on dramatycznie i zwierzęta nie są już celebrowane jako pożywienie, więc obrazy przedstawiające mięso są odbierane jako makabryczne. Według niej fakt, że dla nas mięso to coś, co zapakowane w plastik przywozimy $\mathrm{z}$ supermarketu do domu, sprawił, że nie kojarzymy zwierząt $\mathrm{z}$ mięsem ${ }^{59}$. Zjadanie mięsa stało się czynnością, której nie towarzyszy refleksja nad tym, co wiąże się z pozyskaniem takiego pożywienia, dlatego istotnym wydaje się przypominanie o tym przez sztuki wizualne. Co więcej, jak twierdzi Hal Foster:

[...] niektóre ze współczesnych dzieł sztuki odmawiają wzięcia na siebie tradycyjnego obowiązku łączenia wyobrażeniowego i symbolicznego przeciwko Realnemu. Wydaje się, że chcą one sprawić, by spojrzenie zaczęło lśnić, przedmiot zajął pierwszy plan, a Realne istniało w całej chwale (lub grozie) swego pulsującego pożądania, lub przynajmniej próbują wywołać ten wzniosły $\operatorname{stan}^{60}$.

Sztuka mięs(n)a próbuje sprowokować do innego myślenia o mięsie, próbuje wywołać stan, w którym dokona się swoista przemiana w patrzącej osobie. Miejmy nadzieję, że zderzenie z Realnym mięsa będzie bodźcem na tyle silnym, spojrzeniem wystarczająco lśniącym, żeby prowadziło do przewartościowania własnego

57. Helena Pedersen, Terror from the Stare: Visual Landscapes of Meat Production, „Antennae. The Politics of Meat", Autumn 2010, Issue 14, s. 36.

58. Pedersen, Terror from the Stare..., s. 37.

59. Claire Brunner, The Flesh House, „Antennae. The Death of the Animal”, Spring 2008, Issue 5,s. 23.

60. Foster, Powrót Realnego, s. 170. 
wyobrażenia na temat mięsa. Ci, którzy zdają sobie sprawę z grozy Realnego mięsa, grozy towarzyszącej pozyskiwaniu go dla rzeszy klientów oczekujących na coraz większe ilości tego „towaru” za coraz niższą cenę, z pewnością docenią starania artystów próbujących sprowokować nas do zatrzymania się przez danym obiektem sztuki (wykonanym z tego specyficznego materiału, czyli mięsa, albo odsyłającego do jego źródła, czyli zwierząt) i refleksji. Zaprezentowane tu prace różnią się między sobą pod względem zastosowanych technik, środków wyrazu czy też walorów estetycznych. Łączy je natomiast fakt, że problematyzują mięso, które jest obecnie zarówno tematem etycznym i politycznym. Nie wszystkie $\mathrm{z}$ omawianych tutaj prac były tworzone, jak w przypadku pracy Banksy'ego czy Sue Coe, z oczywistym zamiarem zwrócenia uwagi na ukrywanie rzeczywistego pochodzenia mięsa. Jednakże, wszystkie uRealniają mięso niezależnie od zastosowanych form artystycznych. 
